\title{
Identification and characterization of genes that control fat deposition in chickens
}

\author{
Hirwa Claire D'Andre ${ }^{1,3^{*}}$, Wallace Paul ${ }^{2}$, Xu Shen $^{3}$, Xinzheng Jia ${ }^{3}$, Rong Zhang ${ }^{3}$, Liang Sun ${ }^{3}$ and Xiquan Zhang ${ }^{3}$
}

\begin{abstract}
Background: Fat deposits in chickens contribute significantly to meat quality attributes such as juiciness, flavor, taste and other organoleptic properties. The quantity of fat deposited increases faster and earlier in the fastgrowing chickens than in slow-growing chickens. In this study, Affymetrix Genechip ${ }^{\oplus}$ Chicken Genome Arrays 32773 transcripts were used to compare gene expression profiles in liver and hypothalamus tissues of fast-growing and slow-growing chicken at 8 wk of age. Real-time RT-PCR was used to validate the differential expression of genes selected from the microarray analysis. The mRNA expression of the genes was further examined in fat tissues. The association of single nucleotide polymorphisms of four lipid-related genes with fat traits was examined in a $F_{2}$ resource population.

Results: Four hundred genes in the liver tissues and 220 genes hypothalamus tissues, respectively, were identified to be differentially expressed in fast-growing chickens and slow-growing chickens. Expression levels of genes for lipid metabolism (SULT1B1, ACSBG2, PNPLA3, LPL, AOAH) carbohydrate metabolism (MGAT4B, XYLB, GBE1, PGM1, HKDC1)cholesttrol biosynthesis (FDPS, LSS, HMGCR, NSDHL, DHCR24, IDI1, ME1) HSD17B7 and other reaction or processes (CYP1A4, CYP1A1, AKR1B1, CYP4V2, DDO) were higher in the fast-growing White Recessive Rock chickens than in the slow-growing Xinghua chickens. On the other hand, expression levels of genes associated with multicellular organism development, immune response, DNA integration, melanin biosynthetic process, muscle organ development and oxidation-reduction (FRZB, DMD, FUT8, CYP2C45, DHRSX, and CYP2C18) and with glycol-metabolism (GCNT2, ELOVL 6, and FASN), were higher in the XH chickens than in the fast-growing chickens. RT-PCR validated high expression levels of nine out of 12 genes in fat tissues. The G1257069A and T1247123C of the ACSBG2 gene were significantly associated with abdominal fat weight. The G4928024A of the FASN gene were significantly associated with fat bandwidth, and abdominal fat percentage. The C4930169T of the FASN gene was associated with abdominal fat weight while the A59539099G of the ELOVL 6 was significantly associated with subcutaneous fat. The A8378815G of the DDT was associated with fat band width.
\end{abstract}

Conclusion: The differences in fat deposition were reflected with differential gene expressions in fast and slow growing chickens.

Keywords: Chicken, Fat deposition, Genes

\section{Background}

Fat deposition is a crucial aspect in modern chicken breeding schemes because it is associated with selection for increased body weight in broilers [1-7]. The growth of broiler chicken is accompanied by an increased

\footnotetext{
* Correspondence: chirwa02@yahoo.fr

${ }^{1}$ Rwanda Agriculture Board, Research Department, P. O Box 5016, Kigali, Rwanda

${ }^{3}$ Department of Animal Genetics, Breeding and Reproduction, College of Animal Science, South China Agricultural University, Guangzhou, Guangdong 510642, China

Full list of author information is available at the end of the article
}

percentage of body fat with a concomitant increase in the mass of abdominal and visceral fat [8]. The quantity of fat deposited increases faster and earlier in fastgrowing chickens than in slow-growing chickens [9-12]. Excessive adiposity is a problem in modern broiler industry [13]; and needs to be controlled to reduce negative effects on productivity, acceptability, and health of consumers. In meat-type chickens, excessive adipose tissue decreases both feed efficiency during rearing and the yield of lean meat after processing. However, fat is the major contributor to meat flavor; and the presence of

\section{Biomed Central}

(c) 2013 Claire D'Andre et al.; licensee BioMed Central Ltd. This is an open access article distributed under the terms of the Creative Commons Attribution License (http://creativecommons.org/licenses/by/2.0), which permits unrestricted use, distribution, and reproduction in any medium, provided the original work is properly cited. 
intramuscular fat confers high eating quality of meat. Therefore, regulating fat deposition plays an important role in broiler chicken production.

In birds, lipogenesis, takes place primarily in the liver whereas adipocyte serves as the storage site for triglycerides [14]. Hepatic lipogenesis contributes 80 to $85 \%$ of the fatty acids stored in adipose tissue [15] because lipogenic activity in chickens is much greater in the liver than in adipose tissue [16-18].

In the past decade, genetic mechanisms underlying chicken fat deposition were widely studied but few studies were conducted to determine the gene expression involved in pathways as well as mechanisms that lead to adiposity in chickens [19]. In the present study, fastgrowing White Recessive Rock chickens (WRR) and slow-growing Xinghua chickens $(\mathrm{XH})$ were used to characterize specific genes for fat deposition in chickens. Global gene expression patterns within the liver and hypothalamus tissue of WRR and $\mathrm{XH}$ chickens were determined using Partek GS 6.4 Affymetrix Genechip Chicken Genome Arrays and the differentially expressed genes were identified. Some of the differentially expressed genes were validated by determining their mRNA expression in liver, hypothalamus and fat tissues. The association of single nucleotide polymorphisms of the genes with chicken fat traits was also investigated.

\section{Materials and methods Chicken populations}

Eight WRR $(4 \hat{\imath}+4+$, Institute of Animal Science, Guangdong Academy of Agricultural Sciences, Guangzhou, China), and $8 \mathrm{XH}$ chickens $(4 \hat{\odot}+4$ 우, Fengkai Zhicheng Poultry Breeding Company, Guangdong, China), were used for differential expression observation with microarray hybridization. All the birds were fed a nutritionally balanced corn-soybean diet [20]. The birds had free access to water. They were slaughtered at $8 \mathrm{wk}$ of age, and the liver and hypothalamus were excised, snapped frozen in liquid nitrogen and stored at $-80^{\circ} \mathrm{C}$ until required for further analyses.

Six sets of WRR $(3 \hat{\partial}+3$ ) , and another six of XH $(3 \hat{\jmath}+3$ q $)$, were used to study mRNA expression of the SULT1B1, PNPLA3, GPAM, ELOVL6, LPL, FASN, $A C S B G 2, F D P S$, and FRZB genes in abdominal fat, subcutaneous fat, breast muscle, and pituitary tissues in the liver and hypothalamus tissues.

For association analysis, an $\mathrm{F}_{2}$ resource population was constructed by crossing WRR with $\mathrm{XH}$ chickens [21]. The fat traits such as abdominal fat weight, subcutaneous fat thickness, fat band width, abdominal fat percentage were recorded in all $F_{2}$ full-sib individuals.

\section{Ethics statement}

The study was approved by the Animal Care Committee of South China Agricultural University (Guangzhou, People's Republic of China). Animals involved in this study were humanely sacrificed as necessary to ameliorate their suffering.

\section{Microarray hybridization and data preprocessing}

Total RNA was isolated from frozen tissues $(50 \mathrm{mg})$ using TRIzol reagent (Invitrogen, CA, USA) according to the manufacturer's instructions. Total RNA concentration was determined by spectrophotometry. The RNA labelling and microarray hybridization were carried out according to the Affymetrix Expression Analysis Technical Manual (Biochip Corporation, Shanghai, China). The arrays were scanned using the Affymetrix Scanner 3000.

The GeneChip Chicken Genome Array used in the present study was created by Affymetrix Inc. (Santa Clara, USA) at the end of 2006, with comprehensive coverage of over 38,000 probe sets representing 32,773 transcripts corresponding to over 28,000 chicken genes (Chicken Genome Sequencing Consortium 2.1). Sequence information for this array was selected from the following public data sources: GenBank, UniGene and Ensembl.

Data normalization was used to eliminate dye-related artifacts. Consecutive filtering procedures were performed to normalize the data, and to remove noise derived from absent genes, background, and nonspecific hybridizations. Comparisons of expression levels were performed for each gene, and genes with the most significant differential expression $(P<0.05)$ were retained. Raw data sets were normalized to total fluorescence, which represents the total amount of RNA hybridized to a microarray, using the Partek GS 6.4 (Affymetrix Genechip ${ }^{\circ}$ Chicken Genome Arrays, USA). QVALUE was used to obtain false-discovery rates (FDR).

The data obtained were subjected to Partek GS 6.4 for comparison using Affymetrix Expression Console Software, for expression algorithm robust multi-array (RMA) analysis. Multivariate ANOVA was used to determine significant differences among the replicates. Differentially expressed genes between WRR and XH chickens were identified by cutoff of fold-change (fold change) $\geq$ 2 and $P<0.05$. Molecular functions of differentially expressed genes were classified according to molecule annotation system (MAS) 3.0 (http://bioinfo.capitalbio. $\mathrm{com} / \mathrm{mas} 3 /$ ). Database from the Kyoto Encyclopedia of Genes and Genomes (KEGG) were used for pathway analysis on differentially expressed genes using AgriGO (GO Analysis Toolkit and Database for Agricultural Community) http://bioinfo.cau.edu.cn/agriGO/) and Database for Annotation, Visualization and Integrated Discovery 
(DAVID) Bioinformatics Resources (http://david.abcc. ncifcrf.gov/).

\section{Validation of the differential expression with real-time RT-PCR}

The primers were designed based on the published cDNA sequences of SULT1B1, the LPL, ELOVL6, ACSBG2, SCD5, FADS1, PNPLA3, GAPDH, BEAN, SLC22A2, DDT, PLA2G12A, and $18 S$ genes (http:// www.ncbi.nlm.nih.gov) using GENETOOL software (BioTools, Alberta, Canada). The RNA was reversetranscribed using the RevertAid Fist Strand cDNA Synthesis (Toyobo, Japan). After reverse transcription, the cDNA of the selected genes were amplified by real-time reverse transcription PCR. The relative level of each mRNA normalized to the $18 \mathrm{~s}$ gene was calculated using the following equation: fold change $=$

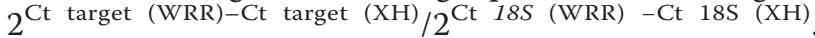

The linear amount of target molecules relative to the calibrator was calculated by $2^{-\Delta \Delta C T}$. Therefore, all gene transcription results are reported as the $n$-fold difference relative to the calibrator. Specificity of the amplification product was verified by electrophoresis on a $0.8 \%$ agarose-gel. The results were expressed as mean $\pm \mathrm{SE}$.

Fat tissue expression of the differential expression genes with real-time RT-PCR studies

The same primers as those used in validation were used for determining fat tissue expression. The real-time RTPCR reactions were performed using the iCycler RealTime PCR detection System. Each sample reaction was ran in triplicate and the expression quantified as the number of cycles (CT) after which fluorescence exceeds the background threshold minus the CT for the housekeeping control $(\triangle \mathrm{CT})$. The calculation of absolute mRNA levels was based on the PCR efficiency and the threshold cycle $(\mathrm{Ct})$ deviation of unknown cDNA versus the control cDNA. The quantitative values were obtained from the $\mathrm{Ct}$ values, which were the inverse ratios relative to the starting PCR product. The linear amount of target molecules relative to the calibrator was calculated by $2^{-} \Delta \Delta C T$. Briefly, the relative levels of each mRNA were expressed as the same as above.

\section{SNP identification and association analysis}

Tree variation sites were identified in intronic of chicken genes ACSBG2, FASN and ELOVL6; and one variation site was identified as non synonymous of chicken $A C S B G 2$ and synonymous coding region of chicken $D D T$ gene by using GENBANK (Table 1).

The data for association study were analyzed by ANOVA (SAS 8.1). The statistical significance threshold was set at $P<0.05$. Values were expressed as the mean \pm SEM, and the differences in the means were compared using Duncan's Multiple Range Test at 5\% level of significance.

\section{Results}

Differentially expressed genes in fast-growing WRR and slow-growing $\mathrm{XH}$ chickens at $\mathbf{8} \mathrm{wk}$ of age

After normalization and statistical analyses, 400 and 220 genes with at least 2 -fold differences were identified $(P$ $<0.05, F C \geq 2$ ) in liver and hypothalamus tissues of WRR and $\mathrm{XH}$ chickens, respectively. When fast-growing WRR chickens were compared with slow-growing $\mathrm{XH}$ chickens, 214 and 91 genes were up-regulated, and 186 and 129 genes were down-regulated in liver and hypothalamus tissues (Figure 1A and B; Tables 2 and 3).

In the liver, lipid metabolism genes viz SULT1B1, $A C S B G 2, \quad L P L, A A C S, \quad P N P L A 3$, were up-regulated while $A O A H$ gene was down-regulated. The carbohydrate metabolism genes: MGAT4B, XYLB, GBE1, PGM1, and $H K D C 1$, were up-regulated (Table 2; Figure 1A). The fatty acid biosynthesis genes, ELOVL6 and FASN, cholesterol biosynthesis genes, LSS, HMGCR, FDPS, $D H C R 24$, malate metabolism process gene, $M E 1$, proline biosynthesis process genes, PYCR2 and ALDH18A1, oxidation-reduction reactions genes, CYP1A4, CYP1A1 similar to aldose reductase, AKR1B1, CYP4V2, and DDO, cyclic nucleotide catabolic process gene, N4BP2L1, and multicellular organism development genes, SEMASA and

Table 1 The identified SNPs of the 4 fat deposition related genes

\begin{tabular}{llllll}
\hline Variation ID & Genes name & Chr. & Position on chromosome (bp) & Consequence to transcript & Allele \\
\hline rs10731268 & ACSBG2 & 28 & 1257069 & NON_SYNONYMOUS_CODING & G/A \\
rs15248801 & ACSBG2 & 28 & 1247123 & INTRONIC & INTRONIC \\
rs15822158 & FASN & 18 & 4928024 & INTRONIC \\
rs15822181 & FASN & 18 & 4930169 & INTRONIC & G/A \\
rs15822181 & ELOVL6 & 4 & 59539099 & SYNONYMOUS_CODING \\
rs14092745 & DDT & 15 & 8378815 & A/G \\
\hline
\end{tabular}

SNP position was determined based on the reported SNP in ensembl http://www.ensembl.org/biomart/martview.

ACSBG2, acyl-CoA synthetase bubblegum family member 2; FASN, fatty acid synthase; ELOVL6, elongation of long chain fatty acids; DDT,

D-dopachrome tautomerase. 


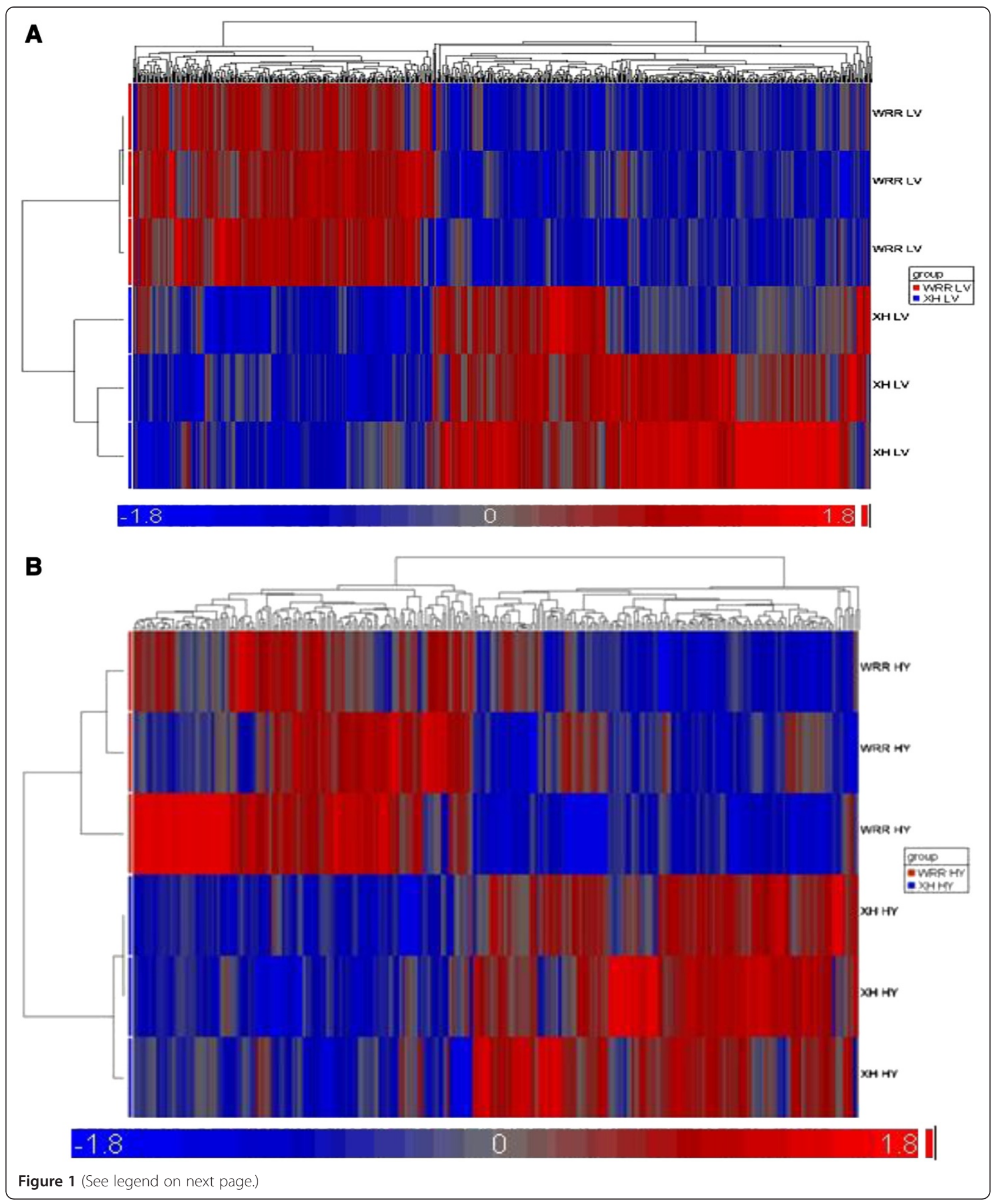


(See figure on previous page.)

Figure 1 Heat maps of differentially expressed genes of FG and SG chicken during developmental stages of liver and hypothalamus tissue. A Heat map of differentially expressed genes of FG and SG chicken during developmental stages of liver tissue. The red color represents fast growing chicken (WRR) genes while the blue color represents the slow growing chicken (XH) genes. The fold changes were arranged from -1.8 up to $1.8(P<0.05)$. WRRLV means liver tissue from White Recessive chickens. XHLV means liver tissue from Xinghua chickens. B Heat map of differentially expressed genes of FG and SG chicken during developmental stages of Hypothalamus Tissue. The red color represents fast growing chicken (WRR) genes while the blue color represents the slow growing chicken (XH) genes. The all identified gene, fold changes were arranged from -1.8 up to $1.8(P<0.05)$. WRRHY means Hypothalamus tissue from White Recessive chickens. XHHY means Hypothalamus tissue from Xinghua chickens.
C1orf107, were identified highly expressed in WRR chickens. In contrast, genes highly expressed in $\mathrm{XH}$ chickens were associated with multicellular development, $F R Z B$, immune response, DNA integration, melanin biosynthetic process, $D D T$, muscle organ development, $D M D$, transforming growth factor beta receptor signaling pathway, FUT8, and oxidation-reduction, CYP2C45, DHRSX, $M I C A L 1$, and $C Y P 2 C 18$. In addition, the genes for the biosynthesis of steroids and fatty acid, ELOVL6, and FASN were also observed highly expressed in $\mathrm{XH}$ chickens (Table 2; Figure 1). The metabolic process genes, ACSM5 (hypothetical protein), were down- regulated by 5- fold, while another metabolic process genes, ENPEP, were upregulated by 5 - fold (Table 2 ).

In the hypothalamus, the cyclic nucleotide catabolism gene, N4BP2L1, was up-regulated in fast growing WRR chickens by a 3.7 -fold change. The negative regulation of endothelial cell proliferation gene, TNFSF15, was upregulated by a 2.5 -fold change. The proteolysis gene, $I T G B L 1$, the protein amino acid phosphorylation genes, $S G K 1$ and RIPK2, are up-regulated in the WRR chickens. The copper ion transport gene, SLC31A1, was localized on chr17:1874758-1884555, and was up-regulated in the WRR chickens by a 7.3-fold change. The PODXL, RAD54B, $P O D X L, P M P 2$ and TMSB10, were up-regulated in the WRR chickens. The melanin biosynthesis gene, $D D T$, ion transport genes, SLC22A2, and GLRA1, lipid metabolism process gene, $P 20 K$ (also known as $E X-F A B P$ ), cellular amino acid metabolism gene, LOC772201, protein complex gene, ATPAF1, proteolysis genes, FOLH1, $C 1 R$, and $V S P 13 B$, striated muscle contraction gene, $M Y B P C 2$, nitrogen compound metabolism process gene, Vanin1, porphyrin biosynthesis process gene, $F E C H$, and response to stress genes, HSP70, HSP25, and $H S P B 1$, were down-regulated in slow-growing $\mathrm{XH}$ chickens. In addition, the signal transduction genes, similar to KIAA0712 protein, and ANK2, small GTPase mediated signal transduction gene, $R A B 30$, DNA integration gene, LOC770705, amino acid phosphorylation gene, PRKD3, carbohydrate metabolic process gene, CBR1, and NAT13, neuron migration gene, MDGA1, hemophilic cell adhesion gene, $P C D H 24$, sodium transport gene, SLC13A5, regulation of transcript DNA-dependent genes, CREB3L2, and $M L L 3$, were also down-regulated in slow-growing XH chickens (Table 3).

Different gene ontology (GO) terms for biological process were identified in the livers of WRR and XH chickens. The highest GO clustered was in lipid biosynthesis process and fatty acid metabolism process (Figure 2).

In hypothalamus tissue, the GO terms for biological process in the WRR and XH chickens were mostly observed in response to stimulus, response to stress, and response to abiotic stimulus. Pigment metabolic process, melanin metabolic process, response to radiation, response to heat, response to temperature stimulus, leucocyte proliferation, pigment biosynthesis process, lymphocyte proliferation, mononuclear cell proliferation and response to ionizing radiation were also observed (Figure 3).

In the pathway study, a number of lipid-related genes: ACSBG2, FASN, LPL, GPAM, FDPS, and others were identified. The cicardian clock gene, ARNTL also known as Bmal1, was observed.

Based on the pathways, differentially expressed genes participated in several function related to lipid (Tables 2 and 4). The lipid related genes were ACSBG2, SULT1B1, and $L D L R$ of lipid metabolism, $L P L$ of glycerolipid metabolism, and MTTP of lipid transporter activity, FASN and ELOVL6 of biosynthesis of unsaturated fatty acids, LSS, HMGCR, NSDHL, DHCR24, IDI1, of HSD17B7 of biosynthesis of steroid, AGPAT4 and FRZB of triacylglyceride synthesis, GPAM of glycerolipid metabolism, PHOSPHO1 and PTDSS1 of glycerophospholipid metabolism, ATP6V1C2 of oxidative phosphorylation, ACSS2 of glycolysis, GCNT2 of glycosphingolipid biosynthesis - lactoseries, and $M E 1$ of pyruvate metabolism (Figure 3).

In hypothalamus tissue, three genes related to VEGF signaling pathway, four genes related to MAPK signaling pathway, one gene each related to alpha-linolenic acid metabolism, nitrogen metabolism, linoleic acid metabolism, porphyrin and chlorophyll metabolism were identified. Then a homologous recombination, heparan sulfate biosynthesis, ether lipid metabolism, arginine and proline metabolism, arachidonic acid metabolism, N-glycan biosynthesis, glycerophospholipid metabolism, ErbB signaling 
Table 2 Fold-changes of significantly differential expressed genes in WRR and XH chickens

\begin{tabular}{ll}
$\begin{array}{l}\text { Gene } \\
\text { symbol }\end{array}$ & Gene title \\
\hline $\begin{array}{l}\text { Lipid metabolic process } \\
\text { SULT1B1 }\end{array}$ & sulfotransferase family, cytosolic, 1B, member 1 \\
ACSBG2 & acyl-CoA synthetase bubblegum family member 2 \\
LPL & lipoprotein lipase \\
AACS & acetoacetyl-CoA synthetase \\
PNPLA3 & Patatin-like phospholipase domain containing 3 \\
$A O A H$ & acyloxyacyl hydrolase (neutrophil)
\end{tabular}

\section{Carbohydrate metabolic process}

$\begin{array}{ll}\text { MGAT4B } & \begin{array}{l}\text { mannosyl (alpha-1,3-)-glycoprotein } \\ \text { beta-1,4-N-acetylglucosaminyltransferase, iso }\end{array} \\ \text { XYLB } & \text { xylulokinase homolog (H. influenzae) } \\ \text { GBE1 } & \begin{array}{l}\text { glucan (1,4-alpha-), branching enzyme 1 } \\ \text { (glycogen branching enzyme, Andersen dis }\end{array} \\ \text { PGM1 } & \text { phosphoglucomutase 1 } \\ \text { HKDC1 } & \text { hexokinase domain containing } 1\end{array}$

\section{Fatty acid biosynthetic process}

ELOVL6 ELOVL family member 6, elongation of long chain fatty acids

$$
\text { FASN fatty acid synthase }
$$

\section{Cholesterol biosynthetic process}

LSS lanosterol synthase (2,3-oxidosqualene-lanosterol cyclase)

\section{HMGCR 3-hydroxy-3-methylglutaryl-Coenzyme A reductase}

FDPS farnesyl diphosphate synthase (farnesyl pyrophosphate synthetase, dimethylallylt

\section{$P$ value Fold} change

Chromosome alignment s

0.0001

$\begin{array}{ll}0.0001 & 7.689 \\ 0.004 & 5.382 \\ 0.018 & 2.528 \\ 0.021 & 2.507 \\ 0.024 & 3.028 \\ 0.043 & -2.516\end{array}$

chr4:53309684-53311980

chr28:1247898-1259038

chrZ:53399697-53408327

chr15:4477440-4512637

chr1:71256654-71270462

chr2:46723433-46778195

$\begin{array}{lll}8.33 E-05 & 2.178 & \text { chr13:13578206-13590970 } \\ 0.0001 & 2.603 & \text { chr2:6032066-6115406 } \\ 0.0008 & 2.119 & \text { chr1:98522850-98669948 } \\ & & \text { chr8:28644700-28665874 } \\ 0.002 & 2.179 & \text { chr6:11960338-11966483 }\end{array}$

$0.002 \quad 2.181$

$0.029-2840$

chr4:59493262-59560594

chr18:4906222-4942593

$0,001 \quad 2,186$

$0,005 \quad 3,236$

$0,021 \quad 2,167$

$0,026 \quad 2,587$

chr7:6878402-6888484

chrZ:23472632-23474241

chrUn_random:75454457546725

DHCR24 24-dehydrocholesterol reductase

HMGCR 3-hydroxy-3-methylglutaryl-Coenzyme A reductase

\section{Oxidation reduction}

$\begin{array}{ll}\text { CYP1A4 } & \text { cytochrome P450 1A4 } \\ \text { CYP1A1 } & \begin{array}{l}\text { cytochrome P450, family 1, subfamily A, polypeptide 1 } \\ \text { dehydrogenase/reductase (SDR family) X-linked }\end{array} \\ \text { LHRSX } & \begin{array}{l}\text { similar to aldose reductase } \\ \text { CYP2C45 }\end{array} \\ \text { AKR1B1 } & \text { aldochrome P-450 2C45 } \\ \text { MICAL1 } & \begin{array}{l}\text { microtubule associated monoxygenase, } \\ \text { calponin and LIM domain containing 1 }\end{array} \\ \text { CYP2C18 } & \text { cytochrome P450, family 2, subfamily C, polypeptide 18 } \\ \text { CYP4V2 } & \text { cytochrome P450, family 4, subfamily V, polypeptide 2 } \\ \text { DDO } & \text { D-aspartate oxidase }\end{array}$

\section{Cicardian clock genes}

ARNTL aryl hydrocarbon receptor nuclear translocator-like

\section{Transforming growth factor beta receptor signaling pathway}

FUT8 fucosyltransferase 8 (alpha

$(1,6)$ fucosyltransferase)
$0,027 \quad 2,805$

chr8:26011324-26019531

chrZ:23472597-23491333

$\begin{array}{lll}0,001 & 9,342 & \text { chr10:1822784-1826314 } \\ 0,003 & 6,485 & \text { chr10:1806680-1809495 } \\ 0,004 & -2,1001 & \text { chr1:132739051-132944192 } \\ 0,014 & 2,042 & \text { chr1:64269892-64273020 } \\ 0,019 & -5,673 & \text { chr6:17648418-17654233 } \\ 0,028 & 2,788 & \text { chr1:64293981-64312331 } \\ 0,029 & -2,186 & \text { chr26:25422-27136 } \\ & & \text { chr6:18655324-18664396 } \\ 0,040 & -3,214 & \text { chr4:63195381-63202122 } \\ 0,048 & 2,426 & \text { chr3:69194822-69198140 } \\ 0,049 & 2,219 & \\ & & \text { chr5:8501344-8546127 } \\ 0,002 & -2,043 & \\ & & \text { chr5:24711230-24725772 }\end{array}$


Table 2 Fold-changes of significantly differential expressed genes in WRR and XH chickens (Continued)

\begin{tabular}{|c|c|c|c|c|}
\hline \multicolumn{5}{|c|}{ Asparagine biosynthetic process } \\
\hline ASNS & asparagine synthetase & $1,48 \mathrm{E}-05$ & 9,945 & chr2:24628018-24641745 \\
\hline \multicolumn{5}{|c|}{ Melanin biosynthetic process } \\
\hline DDT & D-dopachrome tautomerase & $3,50 \mathrm{E}-05$ & $-13,908$ & chr15:8372896-8375331 \\
\hline
\end{tabular}

Positive values indicated that the genes were up-regulated when fast growing WRR chickens are compared with slow growing $\mathrm{XH}$ chickens.

Negative values meant down-regulation when comparison between WRR and XH chickens are made, Data were significantly different $(P>0,05)$, and fold changes were not smaller than 2 .

"_" meant unknown.

pathway, Wnt signaling pathway were also observed in our present study (Table 5).

\section{Validation of differential expression by real-time RT-PCR}

The mRNA levels of 9 genes involved in fat deposition were further quantified using real-time RT-PCR (Table 6). The level of $18 S$ rRNA was chosen as reference and confirmed to be invariable. The expression levels (normalized to 18S) of the 9 genes were determined. Fold changes of gene expression determined by real-time RT-PCR were compared with the fold changes obtained from microarray analysis (Table 6). The highest fold changes in WRR chickens compared with XH chickens were confirmed in the SULT1B1, ACSBG2, ELOVL6, SLC31A1, and PNPLA3 genes. The lowest fold-changes were observed in the $D D T$ and $B E A N$ genes.

\section{Expression levels of the Fat deposition related genes in the Fat tissues of WRR and XH chickens}

When WRR males were compared with $\mathrm{XH}$ males, the expression of the LPL, FDPS, PNPLA3, GPAM, and SULT1B1 genes were up-regulated, and the FASN, $A C S B G 2$, and $F R Z B$ were down-regulated in the abdominal fat tissue (Figure 4). In the subcutaneous fat tissue, the $L P L, F D P S$, PNPLA3, and SULT1B1 were upregulated, and the FASN, GPAM, ACSBG2, and FRZB genes were down-regulated. In the breast muscle tissues, the FDPS, PNPLA3, GPAM, and FRZB were upregulated, and the $L P L, F A S N, A C S B G 2$, SULT1B1, and ELOVL6 genes were down-regulated (Figure 4). In the pituitary tissues, the $L P L, F A S N$, SULT1B1, and ELOVL6 genes were up-regulated, and the FDPS, PNPLA3, GPAM, ACSBG2, and $F R Z B$ genes were up-regulated (Tables 7, 4 and 5).

\section{Polymorphisms of fat deposition genes associated with fat trait in chickens}

The SNP rs10731268 of the ACSBG2 gene was associated with abdominal fat weight $(P=0.005)$, and abdominal fat percentage $(P=0.022)$. The SNP rs15248801 of the ACSBG2 gene was associated with abdominal fat weight $(P=0.039)$ [Table 8 ]. The SNP rs15822158 of the FASN gene was associated with fat band width $(P=$ $0.0003)$, abdominal fat percentage $(P=0.001)$, and abdominal fat percentage $(P=0.005)$ [Table 9]. The SNP rs15822181 of the FASN gene was associated with abdominal fat weight $(P=0.049)$ while the SNP rs16418687 of the ELOVL6 gene was associated with subcutaneous fat $(P=0.034)$. The SNP rs14092745 of the $D D T$ gene was associated with fat band width $(P=0.048)$ [Table 9, 10].

\section{Discussion}

The approach of selective-fat-deposition-related-genes in animals is a relatively new strategy aimed at improving production efficiency while enhancing meat quality. Efforts to reduce fat deposition in animals include genetic selection, feeding strategies, housing and environmental strategies as well as hormone supplementation. While these efforts have improved production efficiency and reduced carcass lipid deposition, negatively impacts on meat quality were due to reduced intramuscular fat deposition [22]. Based on the comparison of two types of breeds of chicken whose fat deposition and growth rate are exceptionally varied, a functional genomics approach was chosen in order to identify chicken fat-depositionrelated-genes. In this genomic approach, liver tissue was used. The liver is the site of fat synthesis, and hypothalamus, which is a major gland for the endocrine system. Few studies focused on global gene expression surveys in chickens. Wang et al. [19] provided analysis of chicken adipose tissue gene expression profile. Other hepatic transcriptional analyses had been reported, using dedicated chicken $3.2 \mathrm{~K}$ liver-specific microarray [14,23] or a 323 cDNA microarray [24].

Differential gene expressions in liver during the fat developmental stage in fast growing WRR and slow growing $\mathrm{XH}$ chickens were related to lipid metabolism in our study. It has been reported that some genes, e.g. 3hydroxyacyl-CoA dehydrogenase, long chain acyl-CoA thioesterase, fatty-acid elongation enzymes and cytosolic fatty-acid-and acyl-CoA-binding proteins, are known to play key roles in mammalian fat or lipid metabolism [25]. Glyco-metabolism such as glycol-sphingolipids (GCNT2), biosynthesis of steroids, fatty acid biosynthesis (ELOVL6 and FASN) was observed in this study. Collin et al. [26] reported that fast growing chickens developed excessive adiposity besides the high muscle mass 
Table 3 Differentially expressed genes in hypothalamus of WRR and XH chickens

\begin{tabular}{|c|c|c|c|c|}
\hline Gene symbol & Gene title & $P$ value & Fold-change & Chromosomes alignment \\
\hline \multicolumn{5}{|c|}{ Lipid metabolic process } \\
\hline P2OK & quiescence-specific protein & 0,0109 & $-2,402$ & chr17:881078-883996 \\
\hline \multicolumn{5}{|c|}{ Porphyrin biosynthetic process } \\
\hline FECH & ferrochelatase (protoporphyria) & 0,009 & $-2,155$ & chrZ:267090-278253 \\
\hline \multicolumn{5}{|c|}{ Nitrogen compound metabolic process } \\
\hline RCJMB04_35g11 & vanin 1 & 0,0406 & $-2,312$ & chr3:58745711-58758866 \\
\hline \multicolumn{5}{|l|}{ Transport } \\
\hline PMP2 & peripheral myelin protein 2 & 0,031 & 3,405 & chr2:126148069-126152515 \\
\hline \multicolumn{5}{|l|}{ Ion transport } \\
\hline SLC22A2 & solute carrier family 22 (organic cation transporter), member 2 & 0,004 & $-2,123$ & chr3:47342914-47355320 \\
\hline GLRA1 & glycine receptor, alpha 1 (startle disease/hyperekplexia) & 0,035 & $-2,146$ & chr13:12903161-12940509 \\
\hline
\end{tabular}

sodium ion transport member

Copper ion transport

SLCBTA1 solute carrier family 31 (copper transporters), member 1

0,017

un

Response to stress

HSP70 heat shock protein 70

HSP25

Signal transduction

LOC419724 similar to KIAA0712 protein

$0,009 \quad-2,393 \quad$ chr24:1172171-1264246

cyclic nucleotide catabolic process

NABP2L1 NEDD4 binding protein 2-like 1

Negative regulation of endothelial cell proliferation

TNFSF15 tumor necrosis factor (ligand) superfamily, member 15

Regulation of transcription, DNA-dependent

CREB3L2

CAMP responsive element binding protein 3-like 2

MLL3

myeloid/lymphoid or mixed-lineage leukemia 3

Protein complex assembly

ATPAF1

ATP synthase mitochondrial F1 complex assembly factor 1

0,006

3,732

chr1:178835487-178837064

0,027

2,553

chr17:2943951-2959613

Protein amino acid phosphorylation

PRKD3

protein kinase D3

SGK1

serum/glucocorticoid regulated kinase 1

RIPK2

receptor-interacting serine-threonine kinase 2

0,001

$-2,197$

chr1:59488049-59500378

0,008

$-4,110$

chr2:6484781-6486027

chr8:22570693-22574048

0,0005 $\quad-2,745 \quad$ chr3:34793675-34819927

$0,004 \quad 2,419$

$0,013 \quad 2,532$

chr3:58130872-58134430

chr2:129010265-129029220

Proteolysis

FOLH1 folate hydrolase (prostate-specific membrane antigen) 1

0,005

$-2,344$

chr1:191872775-191933212

$C 1 R$

ITGBLI complement component 1, r subcomponent

VPS13B integrin, beta-like 1 (with EGF-like repeat domains)

Positive values simply mean that the genes were up-regulated when WRR chickens are compared with XH chickens. Similarly, negative values mean down-regulation when comparison between WRR and XH chickens is made, Data were significantly different $[P>0,05$ (fold change $\geq 2$ )]. 


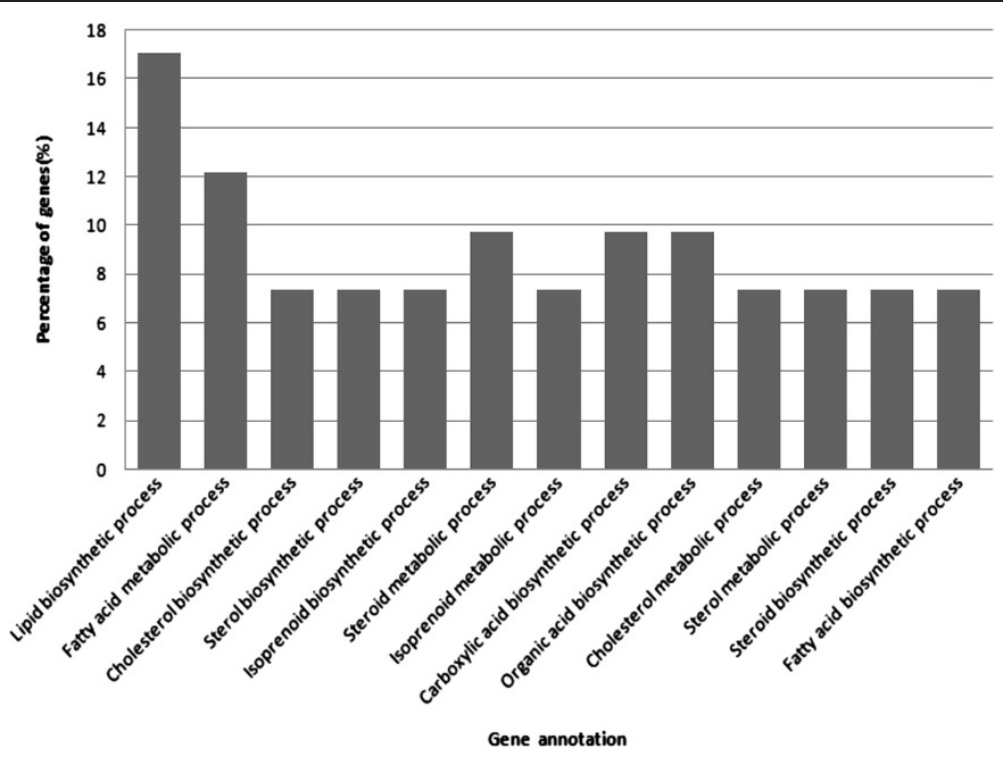

Figure 2 The functional distribution of gene clusters of liver biological process.

resulting from selection. The suggestion is that differential expression of the lipid metabolism related genes might be one of the factors in the differences of fat deposition between fast growing and slow growing chickens at the developmental stage.

The liver is the main site for fatty acid biosynthesis and the fatty acids are then transported to the adipose tissue for storage. The tasks are accomplished through the generation of triglycerides by the liver from fatty acids and L-a-glycerophosphate, packaged into very low density lipoproteins (VLDL), and then, secreted into the blood. The triglycerides in VLDL are processed by the adipose tissue and finally deposited in the central vacuole of the adipocyte. It was suggested that several mechanisms regulate intracellular non-esterified fatty acids composition, including fatty acid transport, acyl CoA synthetases, fatty acid elongases, desaturases, neutral and polar lipid lipases and fatty acid oxidation. Most of these mechanisms are regulated by PPAR alpha or SREBP-1c. Together, these mechanisms control hepatic lipid composition and affect whole-body lipid composition [27]. LPL catalyzes the hydrolysis of plasma lipoproteins, which is a rate-limiting step in

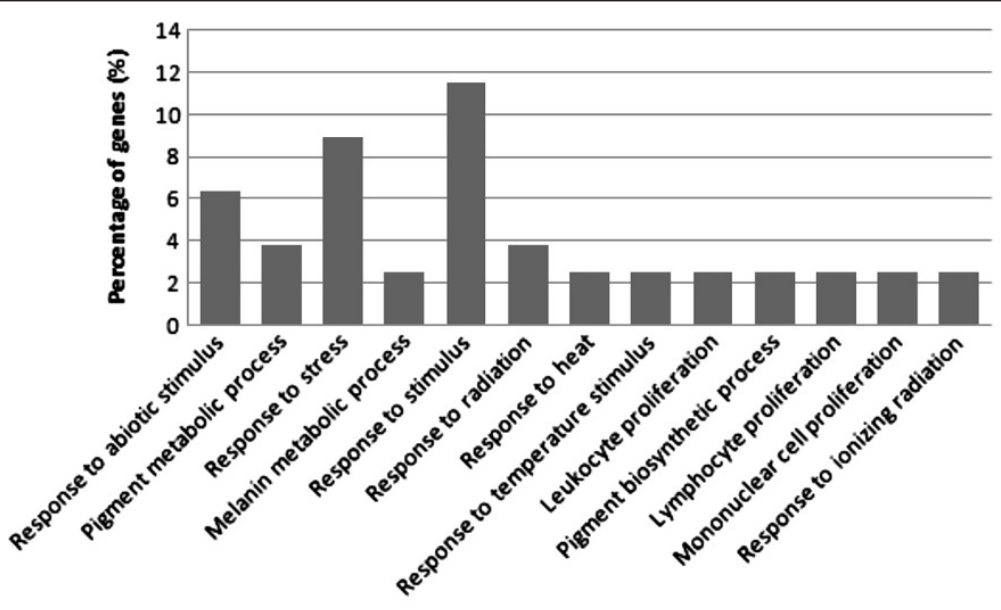

Gene annotation

Figure 3 The functional distribution of gene clusters of hypothalamus biological process. 
Table 4 Pathways of the fat-deposition-related genes in the liver of WRR and XH chickens

\begin{tabular}{|c|c|c|}
\hline Probeset ID & Gene & Pathway \\
\hline $\begin{array}{l}\text { GgaAffx.12964.1. } \\
\text { S1_S_at }\end{array}$ & LSS & Biosynthesis of steroids \\
\hline Gga.13365.1.S1_at & AGPAT4 & Triacylglyceride_Synthesis_BiGCaT \\
\hline $\begin{array}{l}\text { GgaAffx.21515.1. } \\
\text { S1_s_at }\end{array}$ & PTDSS1 & Glycerophospholipid metabolism \\
\hline $\begin{array}{l}\text { GgaAffx.12469.1. } \\
\text { S1_at }\end{array}$ & ELOVL6 & $\begin{array}{l}\text { Biosynthesis of unsaturated } \\
\text { fatty acids }\end{array}$ \\
\hline Gga.7215.2.S1_a_at & HSD17B7 & Biosynthesis of steroids \\
\hline Gga.2334.1.S2_at & PHOSPHO1 & Glycerophospholipid metabolism \\
\hline Gga.2298.1.S1_at & ATP6V1C2 & Oxidative phosphorylation \\
\hline $\begin{array}{l}\text { GgaAffx.5529.1. } \\
\text { S1_at }\end{array}$ & GPAM & Glycerolipid metabolism \\
\hline Gga.8851.1.S1_a_at & $|D| 1$ & Biosynthesis of steroid \\
\hline $\begin{array}{l}\text { GgaAffx.2094.4. } \\
\text { S1_s_at }\end{array}$ & ACSS2 & Glycolysis/Gluconeogenesis \\
\hline Gga.1132.1.S1_at & ME1 & Pyruvate metabolism \\
\hline $\begin{array}{l}\text { GgaAffx.21769.1. } \\
\text { S1_S_at }\end{array}$ & $L P L$ & Glycerolipid metabolism \\
\hline Gga.9630.1.S1_s_at & $L D L R$ & Lipid metabolism \\
\hline Gga.9949.1.S1_at & NSDHL & Biosynthesis of steroids \\
\hline $\begin{array}{l}\text { GgaAffx.12935.1. } \\
\text { S1_s_at }\end{array}$ & DHCR24 & Biosynthesis of steroids \\
\hline Gga.2785.1.S1_s_at & HMGCR & Biosynthesis of steroids \\
\hline Gga.2448.1.S2_at & FASN & Fatty acid biosynthesis \\
\hline $\begin{array}{l}\text { GgaAffx.8101.1. } \\
\text { S1_at }\end{array}$ & $\begin{array}{l}\text { GCNT2; } \\
\text { LOC428479 }\end{array}$ & $\begin{array}{l}\text { Glycosphingolipid biosynthesis - } \\
\text { lactoseries }\end{array}$ \\
\hline $\begin{array}{l}\text { GgaAffx.23852.1. } \\
\text { S1_at }\end{array}$ & MTTP & lipid transporter activity \\
\hline Gga.7792.1.S1_s_at & $A C S B G 2$ & Lipid metabolism \\
\hline Gga.8853.2.S1_a_at & SULTTB1 & $\begin{array}{l}\text { Molecular_function- } \\
\text { transferase_activity }\end{array}$ \\
\hline Gga.4955.1.S1_at & $F R Z B$ & $\begin{array}{l}\text { Adipogenesis; } \\
\text { Cellular_component }\end{array}$ \\
\hline
\end{tabular}

the transportation of lipids into peripheral tissues $[28,29]$. The $L P L$ gene expression in fast growing chicken was 2.5 -fold greater than that in the slow growing type at the developmental stage in this study. In mammals, increased LPL activity is strongly associated with fat deposition and obesity, and these are regulated by both insulin and glucocorticoids according to Fried et al. [30]. The major site of lipogenesis in birds, however, is the liver rather than the adipose tissue [31]. The role of fatty acid-binding protein in the intramuscular trafficking of long-chain fatty acids within intramuscular adipocytes has been studied and found to be related to intramuscular levels in different species $[32,33]$.
Table 5 Pathway of the fat-deposition-related genes expressed in hypothalamus tissue of WRR and XH chickens

\begin{tabular}{|c|c|c|c|c|}
\hline Pathway & Count & $P$-Value & Q-Value & Gene \\
\hline VEGF signaling pathway & 3 & $4,32 \mathrm{E}-05$ & $2,16 \mathrm{E}-05$ & $\begin{array}{c}\text { HSPB1;PLA2G12A, } \\
\text { KRAS }\end{array}$ \\
\hline $\begin{array}{l}\text { MAPK signaling } \\
\text { pathway }\end{array}$ & 4 & $1,02 \mathrm{E}-04$ & $3,40 \mathrm{E}-05$ & $\begin{array}{l}\text { HSPB1;HSP70; } \\
\text { PLA2G12A;KRAS }\end{array}$ \\
\hline $\begin{array}{l}\text { alpha-Linolenic acid } \\
\text { metabolism }\end{array}$ & 1 & 0,015 & 0,001 & PLA2G12A \\
\hline Nitrogen metabolism & 1 & 0,019 & 0,002 & CA3 \\
\hline $\begin{array}{l}\text { Linoleic acid } \\
\text { metabolism }\end{array}$ & 1 & 0,019 & 0,002 & PLA2G12A \\
\hline $\begin{array}{l}\text { Porphyrin and } \\
\text { chlorophyll metabolism }\end{array}$ & 1 & 0,023 & 0,002 & FECH \\
\hline $\begin{array}{l}\text { Homologous } \\
\text { recombination }\end{array}$ & 1 & 0,026 & 0,002 & RAD54B \\
\hline $\begin{array}{l}\text { Heparan sulfate } \\
\text { biosynthesis }\end{array}$ & 1 & 0,026 & 0,002 & HS6ST2 \\
\hline Ether lipid metabolism & 1 & 0,030 & 0,002 & PLA2G12A \\
\hline $\begin{array}{l}\text { Arginine and proline } \\
\text { metabolism }\end{array}$ & 1 & 0,032 & 0,002 & LOC396507 \\
\hline $\begin{array}{l}\text { Arachidonic acid } \\
\text { metabolism }\end{array}$ & 1 & 0,033 & 0,002 & PLA2G12A \\
\hline N-Glycan biosynthesis & 1 & 0,043 & 0,002 & ALG13 \\
\hline $\begin{array}{l}\text { Inositol phosphate } \\
\text { metabolism }\end{array}$ & 1 & 0,052 & 0,0027 & IPMK \\
\hline $\begin{array}{l}\text { Glycerophospholipid } \\
\text { metabolism }\end{array}$ & 1 & 0,056 & 0,002 & PLA2G12A \\
\hline ErbB signaling pathway & 1 & 0,086 & 0,004 & KRAS \\
\hline Wnt signaling pathway & 1 & 0,138 & 0,005 & TCF7L2 \\
\hline
\end{tabular}

Fatty acid synthesis (FAS) occurs during periods of energy surplus and concomitantly its gene expression is down-regulated during starvation in the liver [34], which is the major site of lipogenesis in avian species [35-37]. The regulation of hypothalamic fatty acid synthesis gene expression in response to starvation is similar to that of liver fatty acid synthesis. In birds, like in humans, fatty acid synthesis primarily occurs in the liver. Demeure et al. [38] reported that chicken FASN gene is directly the target of liver cross receptor (LxR) alpha and therefore, expands the role of LxR alpha as a regulator of lipid metabolism. $F A S N$ and GPAM are two enzymes that play central roles in de novo lipogenesis. The G4928024A of the FASN gene is significantly associated with fat band width, abdominal fat percentage, and abdominal fat percentage.

The $D D T$ gene was observed down-regulated in both tissues when fast growing WRR chickens were compared with slow growing $\mathrm{XH}$ chickens. This gene 
Table 6 Comparison of liver tissue gene expression levels between microarray and qRT-PCR

\begin{tabular}{ccc}
\hline Genes & $\begin{array}{c}\text { Microarray } \\
\text { Fold changes in } \\
\text { WRR vs. XH }\end{array}$ & $\begin{array}{c}\text { Real-time PCR } \\
\text { Fold changes in } \\
\text { WRR vs. XH }\end{array}$ \\
\hline SULT1B1 & 4,13 & 3,28 \\
LPL & 2,5 & 2,48 \\
ELOVL6 & 2,18 & 1,76 \\
ACSBG2 & 5,3 & 2,29 \\
PNPLA3 & 3,03 & 4,6 \\
BEAN & $-4,2$ & $-5,76$ \\
SLC31A1 & 7,3 & 1,09 \\
DDT & $-6,59$ & $-0,4$ \\
PLA2G12A & $-2,8$ & $-2,6$ \\
\hline
\end{tabular}

Validation of differentially expressed genes between WRR and XH chickens by RT-PCR.

The data presented indicate the relative mRNA expression of both microarray and qRT-PCR.

Positive values mean that the gene was up-regulated when WRR chickens were compared with XH chickens. Similarly, a negative number means that the gene was down-regulated.

has function in melanization which can play a role in the pigmentation of abdominal fat. It also, has a high correlation with the accumulation of melanin in the skin of the shanks. Melanization of abdominal fascia is not harmful but it may cause severe economic losses to the producer. It was surprising to observe that the FDPS, LSS, HMGCR, NSDHL, DHCR24, IDI1, and HSD17B7 were up-regulated in fast growing WRR chickens. These genes are considered as the ones which has some functions in cholesterol biosynthesis. The glycolytic genes (ACSS2), carbohydrate metabolic and fatty acid biosynthesis were also up-regulated in the WRR chickens. It is suggested that the genes related to cholesterol biosynthesis, carbohydrate metabolic and fatty acid biosynthesis may have influence on fat development.

This study also showed that the genes related to proline biosynthetic process, member 2 of pyrroline-5carboxylate reductase family, member $A 1$ of aldehyde dehydrogenase 18 families, and oxidation reduction, CYP1A4, CYP1A1, AKR1B1, CYP4V2, DDO, and similar to aldose reductase, were differently expressed between the WRR and XH chickens. The CYP2H1, CYP2C45, CYP2C18, MICAL1 and CYP3A37 genes were significantly different in between the WRR and XH chickens. In this study, many lipid-related genes were identified, ACSBG2, FASN, LPL, GPAM, and FDPS. The cicardian clock gene (ARNTL) was observed, it plays a role in glucose, lipid metabolism and adipogenesis [39-41]. Moreover, a network of 11 genes, LPL, ACSBG2, AACS, FASN, LSS, FDPS, SULT1B1, HMGCR, DPP4, FUT8, and PLAU, was observed. Parallel expression patterns of these functionally relevant genes provided strong evidence for their coordinated involvement in lipid biosynthesis, cholesterol biosynthesis and fatty acid degradation in chickens. In chickens, the $A C S B G 2$ gene has been found to play a significant role in lipid metabolism. The present study confirmed this conclusion.

In order to support the results of the microarray study, all the genes used for the mRNA assay were found to have good relationship with fat-related genes as their functions related to lipid metabolism, cholesterol biosynthesis and fatty acid metabolism. Interestingly, the SULT1B1, PNPLA3, GPAM, ELOVL6, $L P L, F A S N, A C S B G 2, F D P S$, and FRZB genes were preferentially expressed in 4 fatty tissues of abdominal fat, subcutaneous fat, breast muscle and pituitary gland when WRR were compared with $\mathrm{XH}$ chickens.
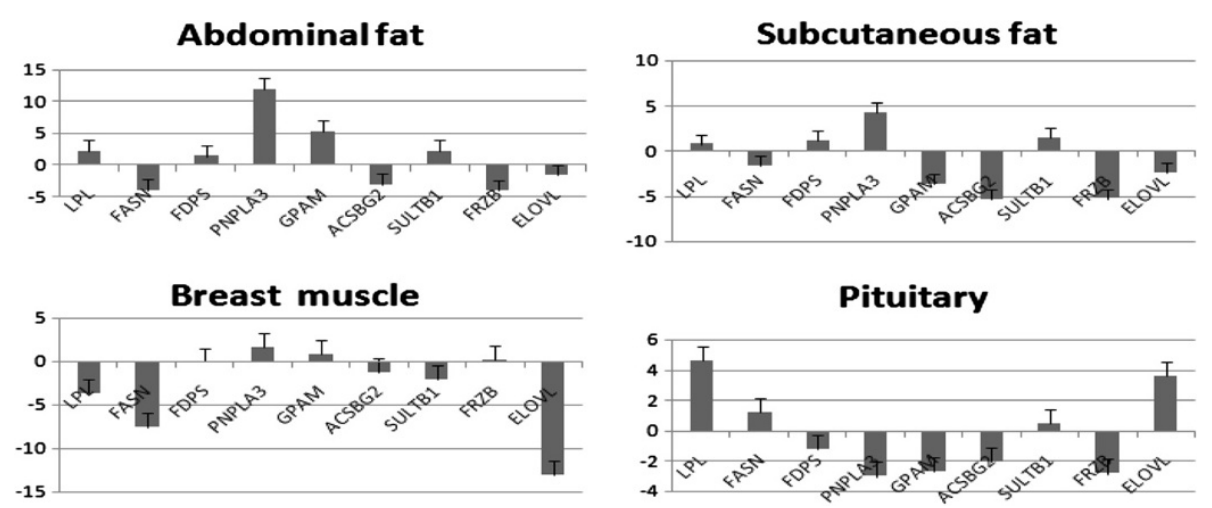

Pituitary

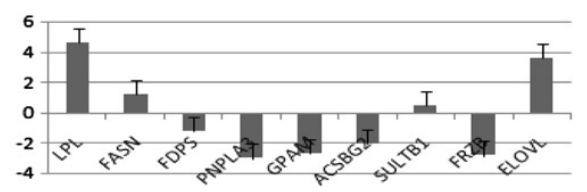

Figure 4 Data presented indicate the different mRNA gene relative expressions (as fold changes) of FG and SG male chicken relative to different fat tissues. Error bars represent the standard errors. Positive values imply genes were up-regulated in fast-growing chicken compared to slow-growing ones. 
Table 7 The localization of differentially expressed fat-related genes

\begin{tabular}{|c|c|c|c|}
\hline Alignments & Gene Symbol & Transcript ID & Gene ontology \\
\hline \multirow[t]{3}{*}{ chrZ:53399697-53408327 } & LPL, ENSGALG00000015425 & NM_205282 & GO:0004465 lipoprotein lipase activity; \\
\hline & & & GO:0004806 triacylglycerol lipase activity; \\
\hline & & & GO:0006629 lipid metabolism; \\
\hline \multirow[t]{2}{*}{ chr4:53309684-53311980 } & SULT1B1, SULT1B1 & NM_204545 & GO:0006629 lipid metabolism; \\
\hline & & & GO:0008202 steroid metabolism; \\
\hline \multirow[t]{2}{*}{ chr28:1247898-1259038 } & ACSBG2(RCJMB04_9i11) & NM_001012846 & 006629 lipid metabolism; \\
\hline & & & GO:0006631 fatty acid metabolism; \\
\hline \multirow[t]{3}{*}{ chr15:4477440-4512637 } & AACS, ENSGALG00000002899 & NM_001006184 & GO:0006629 lipid metabolism; \\
\hline & & & GO:0006631 fatty acid metabolism; \\
\hline & & & GO:0005829 cytosol \\
\hline \multirow[t]{3}{*}{ chr1:71256654-71270462 } & PNPLA3 & XM_416457 & GO:0006629 lipid metabolism; \\
\hline & & & GO:0006629 lipid metabolism; \\
\hline & & & GO:0016042 lipid catabolism \\
\hline \multirow[t]{3}{*}{ chr7:2296059-2312305 } & FRZB, ENSGALG00000002763 & NM_204772 & GO:0017147 Wnt-protein binding; \\
\hline & & & GO:0007275 development; \\
\hline & & & GO:0016055 Wnt receptor signaling pathway \\
\hline chr15:8372896-8375331 & DDT(RCJMB04_2c16) & NM_001030667 & GO:0006583 melanin biosynthesis from tyrosine; \\
\hline chr1:132739051132944192 & DHRSX & XM_001232713 & GO:0055114 oxidation reduction \\
\hline chr7:6879282-6888069 & LSS & NM_001006514 & GO:0006695 cholesterol biosynthesis \\
\hline \multirow[t]{3}{*}{ chr7:22713218-22757360 } & DPP4 & NM_001031255 & GO:0005515 protein binding; \\
\hline & & & GO:0008239 dipeptidyl-peptidase activity; \\
\hline & & & GO:0042803 protein homodimerization activity; \\
\hline chr13:13578206-13590970 & MGAT4B & XM_414605 & GO:0005975 carbohydrate metabolism; \\
\hline \multirow[t]{3}{*}{ chrZ:23472632-23474241 } & HMGCR, ENSGALG00000014948 & NM_204485 & $\begin{array}{l}\text { GO:0004420 hydroxymethylglutaryl-CoA reductase } \\
\text { (NADPH) activity; }\end{array}$ \\
\hline & & & GO:0016491 oxidoreductase activity; \\
\hline & & & GO:0050661 NADP binding; \\
\hline \multirow[t]{3}{*}{ chr5:24711230-24725772 } & ENSGALG00000008078, FUT8 & NM_001004766 & $\begin{array}{l}\text { GO:0008424 glycoprotein 6-alpha-L-fucosyltransferase } \\
\text { activity; }\end{array}$ \\
\hline & & & GO:0046921 alpha(1,6)-fucosyltransferase activity; \\
\hline & & & $\begin{array}{l}\text { GO:0007179 transforming growth factor beta receptor } \\
\text { signaling pathway }\end{array}$ \\
\hline \multirow[t]{3}{*}{ chr6:28077530-28103087 } & GPAM & XM_421757 & GO:0006631 fatty acid metabolism; \\
\hline & & & GO:0019432 triacylglycerol biosynthesis; \\
\hline & & & GO:0040018 positive regulation of body size; \\
\hline \multirow[t]{2}{*}{ chr20:3629311-3638107 } & SGK2 & XM_417346;CR387909 & GO:0004713 protein-tyrosine kinase activity; \\
\hline & & & GO:0005524 ATP binding; \\
\hline \multirow[t]{2}{*}{ chr3:34793675-34819927 } & PRKD3 & XM_419526 & GO:0004713 protein-tyrosine kinase activity; \\
\hline & & & GO:0005524 ATP binding; \\
\hline chr20:2633184-2647420 & ACSS2 & XM_417342 & GO:0006085 acetyl-CoA biosynthesis; \\
\hline Chr1: 64269656-64276867 & LOC418170 & XM_416401 & GO:0055114 oxidation reduction \\
\hline chr6:17648418-17654233 & CYP2C45 & SNM_001001752 & GO:0055114 oxidation reduction \\
\hline \multirow[t]{2}{*}{ chr4:11367346-11377074 } & NSDHL & XM_420279 & GO:0005975 carbohydrate metabolism; \\
\hline & & & GO:0008203 cholesterol metabolism; \\
\hline chrUn_random:7545445-754 & FDPS & XM_422855 & GO:0006695 cholesterol biosynthesis \\
\hline
\end{tabular}


Table 7 The localization of differentially expressed fat-related genes (Continued)

\begin{tabular}{llll}
\hline chr2:144322566-144334593 & SQLE & NM_001030953 & GO:0055114 oxidation reduction; \\
chr8:26011324-26019531 & DHCR24 & NM_001031288 & GO:0016125 sterol metabolism; \\
chr1:64293981-64312331 & AKR1B1 & XR_026805 & GO:0055114 oxidation reduction \\
chr1:118069255-119072613 & DMD & NM_205299 & GO:0007519 striated muscle development; cytoplasm; \\
& & & GO:0016010 dystrophin-associated glycoprotein complex; \\
chr18:4906222-4942593 & FASN, ENSGALG00000002747 & NM_205155;02839 & GO:0045121 lipid raft; \\
& & & GO:0000036 acyl carrier activity; \\
chr4:59493262-59560594 & ELOVL6 & & GO:0004312 fatty-acid synthase activity; \\
chr6:11960338-11966483 & HKDC1 & GO:0006633 fatty acid biosynthesis; \\
& & XM_421579 & GO:0006633 fatty acid biosynthesis \\
chr2:64406040-64411831 & GCNT2 & & GO:0005524 ATP binding; \\
chr1:98522850-98669948 & GBE1 & XM_426036;XM_418950 & GO:0008375 acetylglucosaminyltransferase activity; \\
\hline
\end{tabular}

However, PNPLA3 mRNA level was higher in all tissues in WRR except pituitary tissue, where it expressed lower levels in $\mathrm{XH}$ chicken. PNPLA3, also referred to as adiponutrin, was originally identified as a highly adipose-specific transcript that rapidly responds to nutritional status [42]. The microarray assay demonstrated that there was a 3 times higher expression of the PNPLA3 gene in liver tissue at $8 \mathrm{wk}$ of age in WRR than in $\mathrm{XH}$ chickens. It could be concluded that the PNPLA3 gene is involved in fat deposition.

The microarray data showed that the SULT1B1 is abundantly expressed in liver tissue with 7 fold change in WRR with XH chickens. The gene was reported to be expressed in liver and other numerous extrahepatic tissues [43]. FDPS is an important intermediate in cholesterol and sterol biosynthesis, a substrate for protein farnesylation and geranylgeranylation, and a ligand or agonist for certain hormone receptors and growth receptors. In this study, the FDPS was found to belong to the cholesterol biosythetic group. The FDPS mRNA level was higher in subcutaneous fat and pituitary tissue of WRR female chicken against $\mathrm{XH}$ counterpart.

The GPAM gene plays a vital role in the regulation of cellular triacylglycerol and phospholipid levels [44,45]. In this study, adipose tissues such as abdominal fat and subcutaneous fat were found to have the highest levels of GPAM mRNA expression whereas it was rarely detectable in the liver in the microarray assay. The $F R Z B$ gene (also known as SFRP3) is a member of the secreted frizzled receptor family of soluble proteins which binds to and antagonises Wnt receptor [46]. Wnts are secreted lipid-modified signaling proteins that influence multiple processes in the development of animals. The $F R Z B$ was shown to play a major role in adipogenesis in the microarray analysis of WRR and XH at $8 \mathrm{wk}$ of age. ELOVL6 is involved in de novo lipogenesis and is regulated by dietary, hormonal and developmental factors

Table 8 Association of the G127069A, T1247123C in the ACSBG2 gene with chicken fat traits

\begin{tabular}{|c|c|c|c|c|c|c|c|c|}
\hline \multicolumn{5}{|c|}{ rs10731268 = G1257069A } & \multicolumn{4}{|c|}{$\mathrm{rs} 15248801=\mathrm{T} 1247123 \mathrm{C}$} \\
\hline \multirow[t]{2}{*}{ Traits } & \multirow[t]{2}{*}{$P$ value } & \multicolumn{3}{|c|}{ Genotypes } & \multirow[t]{2}{*}{$P$ value } & \multicolumn{3}{|c|}{ Genotypes } \\
\hline & & $\overline{\mathrm{GG}}$ & GA & AA & & TT & TC & CC \\
\hline Fat Bandwidth (mm) & 0,587 & 0 & $10,05 \pm 6,76(33)$ & $13,85 \pm 1,80(462)$ & 0,66 & $11,65 \pm 7,34(28)$ & $11,34 \pm 3,26(142)$ & $14,75 \pm 2,16(325)$ \\
\hline Abdominal fat weight (g) & $0,005^{* *}$ & 0 & $18,58 \pm 2,27(33) b$ & $27,21 \pm 0,79(463) a$ & $0,0396^{*}$ & $26,07 \pm 3,23(28)$ & $23,68 \pm 1,43(142)$ & $28,06 \pm 0,94(325)$ \\
\hline Abdominal fat percentage & 0,3331 & 0 & $12,16 \pm 9,83(33)$ & $22,02 \pm 2,62(463)$ & 0,3627 & $18,07 \pm 57,75(28)$ & $15,61 \pm 3,44(142)$ & $21,43 \pm 2,27(326)$ \\
\hline
\end{tabular}

Means with different letter are significantly different ${ }^{* *}(P>0.01) ;{ }^{*}(P>0.05)$.

Data are presented at least square means \pm SE.

The number shown in parentheses stands for the selected individuals. 
Table 9 Association of the G4928024A, C4930169T in the FASN gene with chicken fat traits

\begin{tabular}{|c|c|c|c|c|c|c|c|c|}
\hline \multicolumn{5}{|l|}{ rs15822158 = G4928024A } & \multicolumn{4}{|c|}{ rs15822181 = C4930169T } \\
\hline \multirow[t]{2}{*}{ Traits } & \multirow[t]{2}{*}{ P,Value } & \multicolumn{3}{|l|}{ Genotypes } & \multirow[t]{2}{*}{ P.Value } & \multicolumn{3}{|l|}{ Genotypes } \\
\hline & & AA & $A B$ & BB & & $\mathrm{CC}$ & $\mathrm{CT}$ & $\mathrm{TT}$ \\
\hline $\begin{array}{l}\text { Subcutaneous fat thickness } \\
(\mathrm{mm})\end{array}$ & 0,7051 & $4,34 \pm 0,39(14)$ & $3,94 \pm 0,29(26)$ & $4,03 \pm 0,07(438)$ & 0,8198 & $\begin{array}{l}4,02 \pm 0,07 \\
(352)\end{array}$ & $\begin{array}{l}4,12 \pm 0,14 \\
(107)\end{array}$ & $\begin{array}{l}4,03 \pm 0,33 \\
(20)\end{array}$ \\
\hline Fat Bandwidth (mm) & $0,0003^{* *}$ & $\begin{array}{l}10,52 \pm 10,4(14) \\
b\end{array}$ & $\begin{array}{l}44,02 \pm 7,6(26) \\
a\end{array}$ & $\begin{array}{l}11,98 \pm 1,86 \\
(437) \mathrm{b}\end{array}$ & 0,8934 & $\begin{array}{l}14,21 \pm 2,11 \\
(351)\end{array}$ & $\begin{array}{l}12,32 \pm 3,82 \\
(107)\end{array}$ & $\begin{array}{l}11,96 \pm 8,84 \\
(20)\end{array}$ \\
\hline Abdominal fat weight (g) & 0,2155 & $21,98 \pm 4,60(14)$ & $\begin{array}{l}22,47 \pm 3,37 \\
(26)\end{array}$ & $\begin{array}{l}27,28 \pm 0,82 \\
(437)\end{array}$ & $0,0491^{*}$ & $\begin{array}{l}25,97 \pm 0,92 \\
(351)\end{array}$ & $\begin{array}{l}30,54 \pm 1,66 \\
(107)\end{array}$ & $\begin{array}{l}24,85 \pm 3,85 \\
(20)\end{array}$ \\
\hline Abdominal fat percentage & $0,0016^{* *}$ & $\begin{array}{l}15,52 \pm 11,02 \\
(14) b\end{array}$ & $\begin{array}{l}48,12 \pm 0,09 \\
(26) \mathrm{a}\end{array}$ & $\begin{array}{l}18,18 \pm 1,97 \\
(438) \mathrm{b}\end{array}$ & 0,9755 & $\begin{array}{l}19,71 \pm 2,22 \\
(352)\end{array}$ & $\begin{array}{l}20,34 \pm 4,04 \\
(107)\end{array}$ & $\begin{array}{l}18,18 \pm 9,34 \\
(20)\end{array}$ \\
\hline
\end{tabular}

Means with different letter are significantly different ${ }^{* *}(P>0,01) ;{ }^{*}(P>0,05)$.

Data are presented at least square means \pm SE.

The number shown in parentheses stands for the selected individuals.

[47]. In this study, ELOVL6 mRNA level was higher in all tissues of XH chickens than of WRR chickens.

LPL is a glycoprotein enzyme that is produced in several tissues of mammals such as adipose tissue, skeletal muscle, heart, macrophages and lactating mammary gland, but not in the liver of adults $[48,49]$. In chickens, LPL hydrolyzes lipids in lipoproteins, such as those found in chylomicrons and very low-density lipoproteins (VLDL) into three free fatty acid molecules and one glycerol molecule [29,50-52]. In studying the deposition of fat in the abdominal fat pads of chicken, it has become clearer that LPL-catalyzed hydrolysis of triacylglycerol in adipose tissue is a ratelimiting step in fat accumulation [28]. Therefore, the transport and incorporation of exogenous lipids, i.e. plasma VLDL lipoprotein and portomicron, are essential for the deposition of cytoplasmic triglycerides in abdominal adipose tissue. These are characteristics of lipid metabolism in avian species since lipogenic activity is much greater in the liver than in adipose tissue $[28,53,54]$. This study showed that the $L P L$ gene expression was significantly higher in fast-growing chickens than in slow-growing chickens.
The association study provides direct evidence of genes related to fat deposition. In our association study, the A59539099G of the ELOVL6 gene was significantly associated with subcutaneous fat. The A8378815G of the $D D T$ gene was associated with fat band width. The C4930169T of the FASN gene was also found to be associated with abdominal fat weight. G1257069A and T1247123C of the ACSBG2 gene were significantly associated with fat traits. The above results further confirmed that the ELOVL6, DDT, FASN, and ACSBG2 genes are related to chicken fat deposition.

\section{Conclusion}

The differential genes expressions in fast and slow growing chickens show differences in fat developmental stage which is supported by lipid-related genes identified and characterized in these two types of chicken. The findings indicate that the variation of the ACSBG2, FASN, ELOVL 6, and $D D T$ genes were significantly associated with fat deposition.

Table 10 Association of the A59539099G in the ELOVL 6 and the A8378815G in the DDT gene on chicken fat traits

\begin{tabular}{|c|c|c|c|c|c|c|c|c|}
\hline \multicolumn{5}{|c|}{ chr4/ELOVL 6} & \multicolumn{4}{|c|}{ chr, 15/DDT } \\
\hline \multicolumn{5}{|c|}{ rs16418687 = A59539099G } & \multicolumn{4}{|c|}{ rs14092745 = A8378815G } \\
\hline \multirow[t]{2}{*}{ Traits } & \multirow[t]{2}{*}{$P$ value } & \multicolumn{3}{|c|}{ Genotypes } & \multirow[t]{2}{*}{$P$ value } & \multicolumn{3}{|c|}{ Genotypes } \\
\hline & & AA & AG & GG & & AA & AG & GG \\
\hline Subcutaneous fat thickness (mm) & $0,033^{*}$ & $4,05 \pm 0,06(475) a$ & $1,820 \pm 1,04(2)$ & 0 & 0,100 & $4,31 \pm 0,18(60)$ & $4,08 \pm 0,09(229)$ & $3,96 \pm 0,11(185)$ \\
\hline Fat Bandwidth (mm) & 0,867 & $16,34 \pm 3,19(475)$ & $8,08 \pm 49,23(2)$ & 0 & $0,048^{*}$ & $27,04 \pm 5,07(60)$ & $12,02 \pm 2,60(228)$ & $11,55 \pm 2,89(185)$ \\
\hline Abdominal fat weight (g) & 0,338 & $26,84 \pm 0,79(474)$ & $15,15 \pm 12,16(2)$ & 0 & 0,649 & $28,18 \pm 5,54(60)$ & $31,17 \pm 2,83(229)$ & $26,33 \pm 3,16(185)$ \\
\hline Abdominal fat percentage & 0,811 & $23,42 \pm 3,22(475)$ & $11,47 \pm 49,75(2)$ & 0 & 0,254 & $34,17 \pm 7,41(60)$ & $22,17 \pm 3,79(229)$ & $17,25 \pm 4,22(185)$ \\
\hline
\end{tabular}

Means with different letter are significantly different $* *(P>0.01) ;{ }^{*}(P>0.05)$.

Data are presented at least square means \pm SE.

The number shown in parentheses stands for the selected individuals. 


\section{Abbreviations}

WRR: White recessive rock; $\mathrm{XH}$ : Xinghua; RMA: Robust multi-array; MAS: Molecule annotation system; KEGG: Kyoto encyclopedia of genes and genomes; AgriGO: GO analysis toolkit and database for agricultural community; DAVID: Database for annotation, visualization and integrated discovery.

\section{Competing interests}

The authors declare that they have no competing interests.

\section{Authors' contributions}

HCA is a correspondence author, conducted all the experiments and written and approved the final manuscript. WP participated in data analysis and approved the final manuscript. SX participated in data collection, laboratory experiment and approved final manuscript. JX participated in data collection, laboratory experiment and approved final manuscript. ZR participated in data collection, laboratory experiment and approved final manuscript. SL corried out the data analysis and approved final manuscript. ZX guided in gene expression analysis and approved final manuscript.

\section{Acknowledgments}

Funds for this work were partly provided by The Ministry of Higher Education Student Financing Agency of Rwanda, China Scholarship Council and South China Agricultural University, Guangzhou, China. Further support was provided by the Major State Basic Research Development Program, China (project no. 2006CB102107), and the National High Technology Research and Development Program of China (863 Program, project no. 2007AA10Z163).

\section{Author details}

${ }^{1}$ Rwanda Agriculture Board, Research Department, P. O Box 5016, Kigali, Rwanda. ${ }^{2}$ Council for Scientific and Industrial Research (CSIR), Animal Research Institute, P. O. Box AH 20, Accra, Achimota, Ghana. ${ }^{3}$ Department of Animal Genetics, Breeding and Reproduction, College of Animal Science, South China Agricultural University, Guangzhou, Guangdong 510642, China.

Received: 26 March 2013 Accepted: 30 October 2013

Published: 9 November 2013

\section{References}

1. Ricard FH, Rouvier R: Etude de la composition anatomique du poulet. 1. Variabilite de la repartition des differentes parties corporelle chez de coquelets "Bresse-Pile". Anri Zoorerh 1967, 16:23.

2. Proudman W, Mellen J, Anderson DL: Utilization of feed in fast- and slowgrowing lines of chickens. Poult Sci 1970, 49:961-972.

3. Leclercq B, Blum JC, Boyer JP: Selecting broilers for low or high abdominal fat: initial observations. Br Poult Sci 1980, 21:107-113.

4. Becker WA: Genotypic and phenotypic relations of abdominal fat in chickens. Kansas City, Missouri: Presented at the 27th Annual National Breeder's roundtable; 1978.

5. Huan-Xian C, Ran-Ran L, Gui-Ping Z, Mai-Qing Z, Ji-Lan C, Jie W: Identification of differentially expressed genes and pathways for intramuscular fat deposition in pectoralis major tissues of fast-and slow-growing chickens. BMC Genomics 2012, 13:213.

6. Dunnington EA, Siegel PB: Long-term divergent selection for eight-week body weight in white Plymouth rock chickens. Poultry Sci 1996, 75:1168-1179.

7. Zhao SM, Ma HT, Zou SX, Chen WH: Effects of in ovo administration of DHEA on lipid metabolism and hepatic lipogenetic genes expression in broiler chickens during embryonic development. Lipids 2007, 42:749-757.

8. Zhao X, Mo DL, Li AN, Gong W, Xiao SQ, Zhang Y, Qin LM, Niu YN, Guo YX, Liu XH, Cong PQ, He ZY, Wang C, Li JQ, Chen YS: Comparative analyses by sequencing of transcriptomes during skeletal muscle development between pig breeds differing in muscle growth rate and fatness. PLOS One 2011, 6(5):e19774. 1-18.

9. Havenstein GB, Ferket PR, Qureshi MA: Carcass composition and yield of 1957 versus 2001 broilers when fed representative 1957 and 2001 broiler diets. Poult Sci 2003, 82:1509-1518.

10. Jakobsson A, Westerberg R, Jacobsson A: Fatty acid elongases in mammals: their regulation and roles in metabolism. Prog Lipid Res 2005, 45:237-249.
11. Li WJ, Li HB, Chen JL, Zhao GP, Zheng MQ, Wen J: Gene expression of heart and adipocyte-fatty acid-binding protein and correlation with intramuscular fat in Chinese chickens. Anim Biotechnol 2008, 19(3):189-193.

12. Carlborg O, Kerje S, Schütz K, Jacobsson L, Jensen P, Andersson L: A global search reveals epistatic interaction between QTL for early growth in the chicken. Genome Res 2003, 13(3):413-421.

13. Zhao SM, Ma HT, Zou SX, Chen WH, Zhao RQ: Hepatic lipogenesis gene expression in broiler chicken with different fat deposition during embryonic development. J Vet Med 2007, 54:1-6.

14. Cogburn LA, Wang X, Carre W, Rejto L, Aggrey SE, Duclos MJ, Simon J, Porter TE: Functional genomics in chickens: development of integrated systems microarrays for transcriptional profiling and discovery of regulatory pathways. Comp Funct Genomics 2004, 5:253-261.

15. Richards MP, Poch SM, Coon CN, Rosebrough RW, Ashwell CM, McMurtry JP. Feed restriction significantly alters lipogenic gene expression in broiler breeder chickens. J Nutr 2003, 133:707-715.

16. Goodridge AG, Ball EG: Lipogenesis in the pigeon: in vivo studies. Am J Physiol 1967, 213:245-249.

17. O'Hea EK, Leveille GA: Lipogenesis in isolated adipose tissue of the domestic chick (gallus domesticus). Comp Biochem Physiol 1968, 26:111-120.

18. Cai $Y$, Song $Z$, Zhang $X$, Wang $X$, Jiao H, Lin H: Increased de novo lipogenesis in liver contributes to the augmented fat deposition in dexamethasone exposed broiler chickens (Gallus gallus domesticus). Comp Biochem Physiol C Toxicol Pharmacol 2009, 150(2):164-169.

19. Wang HB, Li H, Wang QG, Zhang XY, Wang SZ, Wang YX, Wang XP: Profiling of chicken adipose tissue gene expression by genome array. BMC Genomics 2007, 27(8):193-207.

20. NRC: Nutrient requirements of poultry. 9th edition. Washington, DC: National Academy Press; 1994

21. Lei MM, Nie QH, Peng X, Zhang DX, Zhang XQ: Single nucleotide polymorphisms of the chicken insulin-like factor binding protein 2 gene associated with chicken growth and carcass traits. Poult Sci 2005, 84(8):1191-1198.

22. Dodson MV, Hausman GJ, Guan L, Du M, Rasmussen TP, Poulos SP, Mir P, Bergen WG, Fernyhough ME, McFarland DC, Rhoads RP, Soret B, Reecy JM, Velleman SG, Jiang Z: Lipid metabolism, adipocyte depot physiology and utilization of meat animals as experimental models for metabolic research. Int J Biol Sci 2010, 6:691-699.

23. Duclos MJ, Wang X, Carre W, Rejto L, Simon J, Cogburn LA: Nutritional regulation of global gene expression in chicken liver during fasting and refeeding. San Diego, CA: Plant Animal Genom XII Conf; 2004.

24. Bourneuf E, Herault F, Chicault C, Carre W, Assaf S, Monnier A, Mottier S, Lagarrigue S, Douaire M, Mosser J, et al: Microarray analysis of differentia gene expression in the liver of lean and fat chickens. Gene 2006, 372:162-170.

25. Ashrafi K, Chang FY, Watts JL, Fraser AG, Kamath RS, Julie A, Gary R: Genome-wide RNAi analysis of Caenorhabditis elegans fat regulatory genes. Nature 2003, 421:268-272.

26. Collin A, Swennen Q, Skiba-Cassy S, Buyse J, Chartrin P, Le Bihan-Duval E, Crochet S, Duclos MJ, Joubert R, Decuypere E, Tesseraud S: Regulation of fatty acid oxidation in chicken (Gallus gallus): Interactions between genotype and diet composition. Comp Biochem Physio/ 2009, Part B 153:171-177.

27. Jump DB, Botolin D, Wang Y, Xu J, Christian B, Demeure O: Fatty acid regulation of hepatic gene transcription. J Nutr 2005, 135(11):2503-2506.

28. Sato K, Akiba Y, Chida Y, Takahashi K: Lipoprotein hydrolysis and fat accumulation in Chicken adipose tissues are reduced by chronic administration of lipoprotein lipase monoclonal antibodies. Poult Sci 1999, 78:1286-1291.

29. Sato K, Sook SH, Kamada T: Tissue distribution of lipase genes related to triglyceride metabolism in laying hens (Gallus gallus). Comp Biochem Physiol 2010, 155(1):62-66.

30. Fried SK, Russell CD, Grauso NL, Brolin RE: Lipoprotein lipase regulation by insulin and glucocorticoid in subcutaneous and omental adipose tissues of obese women and men. J Clin Invest 1993, 92:2191-2198.

31. Leveille GA: In vitro hepatic lipogenesis in the hen and chick. Comp Biochem Physiol 1969, 28:431-435

32. Benistant C, Duchamps C, Cohen-Adad F, Rouanet J L, Barre H: Increased in vitro fatty acid supply and cellular transport capacities in cold-acclimated ducklings (Cairina moschata). Am J Physiol 1998, 275:R683-R690.

33. Saez G, Davail $S$, Gentès $G$, Hocquette JF, Jourdan T, Degrace P, Baéza E: Gene expression and protein content in relation to intramuscular fat content in Muscovy and Peki ducks. Poult Sci 2009, 88:2382-2391. 
34. Back DW, Goldman MJ, Fisch JE, Ochs RS, Goodridge AG: The fatty acid synthase gene in avian liver. Two mRNAs are expressed and regulated in parallel by feeding, primarily at the level of transcription. J Biol Chem 1986, 261:4190-4197.

35. Goodridge AG, Ball EG: The Effect of Prolactin on Lipogenesis in the Pigeon. In Vitro Studies. Biochemistry 1967, 6(8):2335-2343.

36. Leveille GA, O'Hea EK, Chakrabarty K: In vivo lipogenesis in the domestic chicken. Proc Soc Exp Biol Med 1968, 128:398-401.

37. Leveille GA, Romsos DR, Yeh YY, O'Hea EK: Lipid biosynthesis in the chick. A consideration of site of synthesis, influence of diet and possible regulating mechanisms. Poult Sci 1975, 54:1075-1093.

38. Demeure O, Duby C, Desert C, Assaf S, Hazard D, Guillou H, Lagarrigue S: Liver $X$ receptor regulates fatty acid synthase expression in chicken. Poult Sci 2009, 88:2628-2635.

39. Shimba S, Ishii N, Ohta Y, Ohno T, Watabe $Y$, Hayashi M, et al: Brain and muscle arnt-like protein-1 (BMAL1), a component of the molecular clock, regulates adipogenesis. Proc Natl Acad Sci U S A 2005, 102:12071-12076.

40. Gómez-Santos C, Gómez-Abellán P, Madrid JA, Hernández-Morante JJ, Lujan $J A$, Ordovas JM, Garaulet M: Circadian rhythm of clock genes in human adipose explants. Obesity 2009, 17(8):1481-5.30.

41. Wu X, Zvonic S, Floyd ZE, Kilroy G, Goh BC, Hernandez TL, et al: Induction of circadian gene expression in human subcutaneous adipose-derived stem cells. Obesity 2009, 15(11):2560-2570.

42. Baulande S, Lasnier F, Lucas M, Pairault J: Adiponutrin, a transmembrane protein corresponding to a novel dietary and obesity-linked mRNA specifically expressed in the adipose lineage. J Biol Chem 2001, 276:33336-33344.

43. Dooley TP, Haldeman-Cahill R, Joiner J, Wilborn TW: Expression profiling of human sulfotransferase and sulfatase gene superfamilies in epithelial tissues and cultured cells. Biochem Biophys Res Commun 2000, 277:236-245.

44. Yazdi M, Ahnmark A, William-Olsson L, Snaith M, Turner N, Osla F, Wedin M, Asztély AK, Elmgren A, Bohlooly-Y M, Schreyer S, Lindén D: The role of mitochondrial glycerol-3 phosphate acyltransferase-1 in regulating lipid and glucose homeostasis in high-fat diet fed mice. Biochem Biophys Res Commun 2008, 369:1065-1070.

45. Palou M, Priego T, Sánchez J, Villegas E, Rodríguez AM, Palou A, Picó C: Sequential changes in the expression of genes involved in lipid metabolism in adipose tissue and liver in response to fasting. Pflugers Arch 2008, 456(5):825-836.

46. Marsit CJ, Houseman EA, Christensen BC, Gagne L, Wrensch MR, et al: Identification of methylated genes associated with aggressive bladder cancer. PLoS One 2010, 5(8):e12334.

47. Kan S, Abe H, Kono T, Yamazaki M, Nakashima K, Kamada T, Akiba Y: Changes in peroxisome proliferator-activated receptor gamma gene expression of chicken abdominal adipose tissue with different age, sex and genotype. Anim Sci J 2009, 80:322-327.

48. Hoenig M, McGoldrick JB, De Beer M, Demacker PNM, Ferguson DC: Activity and tissue-specific expression of lipases and tumor-necrosis factor a in lean and obese cats. Domest Anim Endocrinol 2006, 30:333-344.

49. Albalat A, Saera-Vila A, Capilla E, Gutierrez J, Perez-Sanchez J, Navarro I: Insulin regulation of lipoprotein lipase (LPL) activity and expression in gilthead Sea bream (sparus aurata). Comp Biochem Physiol B 2007, 148:151-159.

50. Sato K, Akiba Y: Lipoprotein lipase mRNA expression in abdominal adipose tissue is little modified by age and nutritional state in broiler chickens. Poultry Sci 2002, 81:846-885.

51. Nie Q, Fang M, Xie L, Shi J, Zhang X: cDNA cloning, characterization, and variation analysis of chicken adipose triglyceride lipase (ATGL) gene. Mol Cell Biochem 2009, 320:67-74.

52. D'André Hirwa C, Yan W, Wallace P, Nie Q, Luo C, Li H, Shen X, Sun L, Tang J, Li W, Zhu X, Yang G, Zhang X: Effects of the thyroid hormone responsive spot 14 \{alpha\} gene on chicken growth and fat traits. Poult Sc. 2010, 89(9):1981-1991.

53. Griffin HD, Hermier D: Plasma lipoprotein metabolism and fattening on poultry. In Leanness in domestic birds. Edited by Leclerca B, Whitehead CC. London: Butterworths; 1988:175-201.

54. Griffin HD, Guo K, Windsor D, Butterwith SC: Adipose tissue lipogenesis and fat deposition in leaner broiler chickens. J Nutr 1996, 122:363-368.

doi:10.1186/2049-1891-4-43

Cite this article as: Claire D'Andre et al:: Identification and

characterization of genes that control fat deposition in chickens. Journal of Animal Science and Biotechnology 2013 4:43.

\section{Submit your next manuscript to BioMed Central and take full advantage of:}

- Convenient online submission

- Thorough peer review

- No space constraints or color figure charges

- Immediate publication on acceptance

- Inclusion in PubMed, CAS, Scopus and Google Scholar

- Research which is freely available for redistribution 